\title{
REPORTED SPEECH IN RUSSIAN AND ITALIAN: VERBS OF SPEECH AND PARTICLES
}

\author{
ELIZAVETA KHACHATURYAN \\ University of Oslo
}

\section{AB S T R AC T}

The present paper describes a well-known phenomenon: languages without a special grammatical category to transmit reported speech often do so by lexical means. The analysis focuses on the Russian particles mol and deskat' - formed from the Old Russian verbs of speech - and their Italian correspondences. Using the semantico-contextual approach, the description offered here helps to formulate the semantics of the two particles and to find their contextual correspondences in Italian.

\section{[1] INTRODUCTION}

In different languages there are various means of transmitting the words of others without assuming responsibility for what is said (Guentcheva 1996, 2011). The analysis of this phenomenon is based on different theorethical approaches: in particular, the notion of evidentiality is often used in this case (e.g. papers of CHRONOS conferences ${ }^{1}$ held every two years, (Coltier et al. 2009) where different terminology and approaches are discussed). Some languages have special grammatical categories for this; others use lexical means (Dendale \& Coltier 2011).

This article focuses on Italian and Russian, neither of which has a special mood for this purpose. Grammars (in particular, Salvi \& Vanelli (2004)) point out that in Italian the conditional mood can be used with a reportative function. This is called the "journalistic" use, and it is widespread in the language of the mass media (see (1) below). This conditional often appears together with some expressions showing the disengagement of the speaker - i.e., secondo lui (in his opinion, according to someone (examples (2)-(3)). But it can be also used in the spoken language in the repetition of the other's words and it will be interpreted as disagreement (4).

(1) Caduto l'aereo in Nuova Arizona. Il pilota sarebbe sopravissuto.

'A plane went down in New Arizona. The pilot [conditional mood, past tense] survived.'

[1] CHRONOS is a series of conferences devoted to current research on the morphology, syntax, semantics, and pragmatics of markers of tense, aspect, modality and evidentiality (TAME). 
(2) Secondo una corrente teologica Maria si sarebbe addormentata.

'According to one theological school Maria fell [conditional mood, past tense] asleep.'

(3) Secondo il New York Times, sarebbe ormai guerra aperta tra USA ed Europa.

'According to The New York Times, there is [conditional mood, past tense] an open war between the USA and Europe.'

(4) - Cretino! - Io sarei il cretino?! (a real example taken from a movie)

'- Stupid! - I am [conditional mood, present tense] stupid?!'

In Russian there are two particles - mol and deskat' - that serve what could be defined as a reportative function. Dictionaries identify mol and deskat' as the textual markers of another speaker's words.

If the conditional mood in Italian and the Russian particles mol and deskat' have both the same (reportative) function, one can suppose that to translate the Russian particles one could use the conditional and vice versa. But in reality mol and deskat' never correspond to the Italian conditional.

The aim of the present analysis will be to discover the real role of mol and deskat' and to find the real correspondences of these two particles in Italian.

\section{[2] RUSSIAN PARTICLES: SOME METHODOLOGICAL REMARKS}

The methodology of this analysis is the semantico-contextual approach to the description of discourse markers elaborated by French and Russian linguists and based on Antoine Culioli's theory of enunciation (Culioli 1990). Within the framework of this approach the particles are considered as part of a larger group of discourse markers (DMs) and are described, like all linguistic units, across several regular formal properties that help to formulate their semantics. Among these regular properties there are the features of the scope, the position of the discourse marker, and the prosodic characteristics (Paillard 1999). In the present article we will analyze the features of the scope based upon which we can draw distinctions between two particles.

The semantico-contextual approach is especially helpful for a contrastive analysis of DMs because it gives the same formal criteria for a description of different languages. To explain the advantages of this approach we have to introduce briefly the class of DMs.

It is well known, that DMs are difficult to categorize. On the one hand, each language has a group of words and expressions that can be defined as DMs; on the other hand, approaches and definitions vary even for one language (Aijmer \& Simon-Vandenbergen 2006; Fischer 2006). There is no well-determined inventory for any of the languages accepted by all the linguists (even for well-studied 
languages, such as English, German or French). Another reason that prevents (or complicates) the generalization is the formal heterogeneity of DMs even in one and the same language. Words and expressions that belong to DMs often have also another grammatical status and a wide range of functions in the language. For example, bien and malheureusment (Fr.) are also adverbs; tiens and disons (Fr.) and guarda and diciamo (It.) are verbal forms; you know (Eng.) and tu vois (Fr.) are combinations of a pronoun and a verb; pravda (Rus.) is also a noun; quoi (Fr.) is an indefinite / interrogative pronoun.

Moreover, DMs are nearly untranslatable. ${ }^{2}$ For example, déjà (Fr.) and schon (Germ.), which have close aspecto-temporal values, have highly divergent discursive uses (Mettrich et al. 1994-1998).

One of the difficulties concerning the class of particles is very well described in the following observation of Waltereit $(2001,1391)$ :

Modal particles are abundant in German, but rather rare in many other languages, e.g., Romance languages. While it is evident that some have more modal particles than others, it seems difficult to conceive of the function of modal particles as being restricted to particular languages. The intuition underlying this article is that if, e.g., the Romance languages have fewer modal particles than German, they should have other means of expressing the same function.

Russian is traditionally considered as a language rich in particles. But the Russian particles are often omitted in the translations because it is difficult to find an appropriate correspondence in another language (Khachaturyan 1998). Nevertheless another language can have "other means of expressing the same function", and the aim of the contrastive analysis should be to discover these other means and may be also to propose them to the translator.

The semantico-contextual approach based on the description of the formal properties of use helps to find the correspondences of DMs and of particles in different languages. In this case the comparison of translations can be used at the last stage of the analysis, as confirmation but not as a main tool of the study.

The present analysis will offer a comparison of contexts of use of Russian particles mol and deskat', and the contrastive description of Russian particles and their semantico-contextual counterpart(s) in Italian. For this reason, the paper is divided in two parts: the first part is dedicated to the analysis of the Russian particles mol and deskat'; in the second part, the Italian examples are analyzed.

We will use two different corpora in this paper. In the first part, the UppsalaTübingen Russian Corpus ${ }^{3}$ created in the Slavic Departments of the universities

[2] See e.g., (Mettrich et al. 1994-1998), with the comparison of German and French.

[3] The Uppsala-Tübingen Russian Corpus contains 1 million words. It was often used by the researchers before the Russian National Corpus (incorporating over 300 million words) was constructed. I use it here because the material for the present analysis was collected several years ago. 
of Uppsala and of Tübingen) will be used. Since the present analysis describes the modern state of the language we used two parts of it: the Contemporary Corpus which includes literary and press contents and the Corpus based on 20th century literature. In the second part, will be used the data from the Italian corpus (CORIS/CODIS) created at the University of Bologne which includes the texts of different genres of 20th century literature ${ }^{4}$. To our knowledge there is no big parallel Russian-Italian corpora. We have checked the RuN corpus where a small Russian-Italian part is present ${ }^{5}$, but there were no examples of Russian particles mol and deskat' in this part.

\section{[3] RUSSiAn PARTICLES: 'MOL' AND 'DESKAt”}

\section{[3.1] Dictionary definitions}

Dictionaries usually define mol and deskat' as completely synonymous particles whose role is to transmit the discourse of another in the text or to mark words in the text as those of another speaker (e.g. monolingual dictionaries of Russian: Ušakov (2000); Evgenjeva (1999)).

But in spite of this similarity, a closer look reveals that the two particles are not interchangeable in all contexts. In general, it is easier to replace deskat' with mol than vice versa. (One reason for this could be the form itself of mol: it has properties of a clitic and is easier to connect with other words. However, we will see below that the other reason is the semantics of mol.) The use of mol is more widespread than that of deskat ${ }^{\prime 6}$, which is often considered by native speakers to be antiquated and inadequate for use in the modern language. An analysis of written journalistic language found a more frequent use of mol than deskat. At the same time in the corpus that we used (which includes literary texts) a large amount of occurrences of deskat' was found. In (5) and (6) below, the particle deskat' is used, but it can not be replaced by mol.

(5) “My predložili, - pišut oni,-- real'no perevesti masterskuju na polnyj xozrassčet (poka on u nas bumažnyj, no podderžki tak i ne polučili. Vydvigaetsja somnitel'nyj argument : deskat' my k etomu ešče ne gotovy".

'We proposed, - they write, - to put the enterprise on a self-supporting basis. But we didn't get any support. A doubtful argument is adduced: deskat', we are not ready for it.'

[4] CORIS is a corpus of written Italian which contains 80 million running words. It consists of a collection of authentic texts in electronic form "chosen by virtue of their representativeness of modern Italian" (http://corpora.dslo.unibo.it/coris_eng.html).

[5] It contains only four texts and approximately 1 million words.

[6] In the Russian National Corpus, in the fiction subcorpus, I have found 2,061 occurences with mol vs. 1,012 occurrences with deskat'; in the non-fiction subcorpus: 2,562 occurrences with mol vs. 1,124 occurrences with deskat'. 
(6) Vosem'desjat pjat' funtov. Tanja otdelila dva samyx zamyzgannyx pjatifuntovika, vložila obratno, usmexnulas'-deskat', čto vy, nikakogo maroderstva ne imelo mesta.

'Eighty-five pounds. Tanja peeled off the two most bedraggled bills, put them back in the wallet, and grinned: deskat', what are you talking about? There wasn't any looting.'

The difference between the two particles can be explained by their semantics, which can be formulated based upon formal features, and especially on the description of the scope, i.e., the part of the enunciation that changes its discourse status under the influence of a discourse marker or a particle.

For the present description it will be useful to distinguish between two positions: that of the first speaker (who describes the situation - we will call him the narrator) ${ }^{7}$ - and that of the second speaker (who constructs the enunciation in a described situation-we will call him the speaker). The narrator can also be speaker if s/he transmits his/her own words that were said in the described situation.

\section{[3.2] Analysis of the scope}

The scope of both particles has the form of a proposition $\mathrm{P}$ that can be an independent phrase or a part of a complex phrase (subordinated or juxtaposed). In both cases $\mathrm{P}$ as a scope of the particle ( $m o l$ or deskat') has the status of words that don't belong to the speaker: these are words of the other. In (7) and (8) the scope of both particles has the form of an independent phrase.

(7) ... a novaja žena, Marta, samoljubivaja ženščina, Galočku znat' ne želaet i ee, Evdokiju Nilovnu videt' ne xočet, nikogda sjuda ne priedet, pis'ma ne prišlet i Nikolaju Demjanoviču priezžat' zapreščaet. Den'gi, mol, posylaj, a bol'še ničego.

'... and the new wife, Marta, a proud woman, doesn't want to know anything about Galočka, and doesn't want to see her, Evdokija Nilovna. She'll never come here or send a letter, and she forbids Nikolaj Demjanovič to come. Send, mol, the money, and nothing else.'

(8) Teper' Mana svobodna ot splava. I ožila malost' rečenka. Xariusy objavilis'. No skol'ko ja iz-za togo vragov nažil! Ot raboty, deskat', odnosel'čan uvel. Rabota xorošim rukam zavsegda syščetsja. I čto za rabota, esli vsem vo vred?!

'Now the river Mana breaks free from the float and livens up a bit. The umbers turned back. But how many enemies I've made! You've caused,

[7] Often there is also the real narrator - the voice of the author, as in (7), for example. But for this description of particles, his/her position is not important. 
deskat', the men from your village to lose their jobs. Those with good hands will always find work. And what is the sense of a job that's done at everyone else's expense?'

In (7), mol $\mathrm{P}$ is inserted in a narrative that reports the account of Evdokija Nilovna: it is not a first person account from Evdokija Nilovna's perspective (cf. the use of the pronoun ee -her -to refer to Evdokija Nilovna); rather, P reproduces the words of the new wife (the speaker) transmitted by the narrator (Evdokija Nilovna).

In (8), deskat' introduces the words of the enemies of the narrator. The enemies constitute the speaker, and $\mathrm{P}$ is an argument against the actions of the narrator.

If $\mathrm{P}$ is part of a complex phrase, it has the form of a subordinate phrase, (13) and (14), or of a juxtaposed phrase (9)-(12). Formally it can be considered indirect speech. In this case the particle and its scope can be preceded not only by verbs of speech (verba dicendi) (9) or by nouns describing the act of the communication or the process of thinking (razgovory, ideja, mysl', argument - conversation, idea, thought, argument, etc.) (12), but also by verbs of emotion or verbs describing gesture (10) and action (11).

(9) Večerom volk i medved' prišli k izbuške lisy i sxoronilis'. /.../ Vdrug vidjat bežit zajats. Pozvali oni ego i govorjat: Ty, zajats, na nogu skor, sbegaj $\mathrm{k}$ lise, skaži, mol, medved' i volk uže prišli.

'In the evening the wolf and the bear came to the fox's house and hid themselves. Suddenly, they saw a hare running past. They summoned him and said: You, hare, run as fast as you can to the fox and tell him, mol, the bear and the wolf have already arrived.'

(10) - Vidiš li, ja očen' staryj, - skazal Enen, ševelja vekoj. (Devočka kivnula: mol, vižu.)

'You see, I am very old,-- said Ehnen moving an eyelid. The girl nodded her head: mol, I see.'

(11) A supruga ego, očen' počtennaja dama, prosto daže prirevnovala pirata k Korovjevu i daže ložečkoj postučala ... i čto ž eto, deskat', nas zaderživajut ... Pora i moroženoe podavat'!

'And his wife, a very respectable lady, was even jealous of Koroviev on account of the pirate and even banged a teaspoon... so what's the big idea, deskat', what's holding us up? It's high time they served us our ice cream!'

(12) “My predložili, - pišut oni, - real'no perevesti masterskuju na polnyj xozrasčet (poka on u nas bumažnyj), no podderžki tak i ne polučili. Vydvigaetsja somnitel'nyj argument: deskat' my k etomu ešče ne gotovy".

'We proposed, - they write, - transferring the enterprise to a self-supporting 
basis. But we didn't get any support. A questionable argument is adduced: deskat', we are not ready for it.'

In spite of the formal status of the indirect speech, the syntax (word order, syntactical constructions) and the vocabulary of the scope P are typical of the spoken language. From this point of view P can be characterized as direct speech.

(13) Vjalo pjaljus' na nego, on prinimaet moju len' za šok i krajne emotsional'no, sotrjasaja moi pleči, načinaet objasnjat', čto on, deskat', ne možet vylovit' menja vtoroj den'.

'I stare at him inertly, he takes my inertia for shock and very emotionally, shaking my shoulders, starts to explain to me, that he, deskat', has been unable to fish me out for two days.'

(14) V svoe vremja bylo nemalo razgovorov po povodu togo, čto vot, mol, u amerikantsev est' “čelnoki”, a u Sovetskogo Sojuza net. Značit, delalsja vyvod, amerikantsy vperedi v kosmičeskoj gonke.

'Once there were many conversations to the effect that, mol, the Americans have space shuttles and the Soviet Union does not. In other words, it was inferred that the Americans are leading in the space race.'

In (13), a spoken, emotionally colored verb (vylovit' - to fish out) is used; in (14), the whole construction (vot $u$ amerikantsev - now in the case of the Americans, lit. there are the Americans) is typical of the spoken language: the demonstrative pronoun vot (there are) situates the phrase in the coordinate system of 'hic et nunc,' in spite of the past tense of the principal phrase.

In particular, the deictic elements used in the scope $\mathrm{P}$ represent a distinct point of view. In (10), the verb vižu (I see) has the form of the first person singular that corresponds to the subject of the phrase (devocka - a girl). The same thing can be observed in (11) and (12): the person presented in the scope - first person plural nas (us) in (11), and my (we) in (12) - indicates the subject of the phrase introduced before by a pronoun of the third person.

\section{[3.3] Semantic properties of mol and deskat'}

Based on the properties of the use of the deictic elements, we can formulate the differences between mol and deskat'.

Mol introduces the words of the speaker (or of the presumed speaker). In (9), the narrator (the bear and the wolf) are addressing the hare, and the phrase introduced by mol corresponds to the words that will be said by the hare. In (10), the narrator who describes the whole situation interprets the gesture of the girl nodding her head; vižu (I see) is the girl's reply. In the two examples below, we can see the same phenomenon: in (15), on (he) becomes ja (I) in the proposition introduced by mol; in (16), firmy SŠA (US firms) correspond to my (we). 
(15) I vot teper' v pis'me, po forme - objasnitel'noj zapiske na imja pervogo sekretarja obkoma, on sglažival ugly: voobšče, mol, etu istoriju s Safronovym ja ploxo znaju.

'And now, in his letter, styled as an accusatory letter addressed to the first secretary of the regional committee, he was trying to tone things down: actually, mol, I don't know much about what's happened with Safronov.'

(16) Firmy SŠA pytalis'v oblasti biotexnologii nekij čut' li ne diktat ustanovit': mol, my pervye vse otkryli /.../

'The US biotech firms were trying to pretty much take over: mol, we were the first to discover everything.'

The scope of deskat' does not always correspond to the words pronounced by the speaker. This is evident if we examine the use of pronouns more closely. In (12), a questionable argument is adduced by somebody else (the speaker is referred to in the passive voice), but in the proposition itself introduced by deskat', the first person plural is used which corresponds to the person of the narrator ( $m y$ predložili - we proposed): otherwise, vy (pronoun second person plural) would be used here. In (13), we find the same principle: on (he - third person masculine singular) indicates the speaker (on in the previous context: he starts to explain to me), while menja (me - first person singular) indicates the narrator. In (17), we can see the same phenomenon: the pronoun mne (to me - first person singular) in the scope of deskat' indicates the narrator who tells the story:

... polučiv neprivyčnyj otpor, vosplamenilsja, oral, est', deskat', v Permskoj oblasti kolxoz-millioner, tam by izbu mne dali besplatno ...

'... after he had received an unexpected rebuff, he started to howl, there is, deskat', in the region of Perm', a kolkhoz-millionaire, there they would give me a house for free ...'

A hypothesis concerning the semantics of both particles was proposed by Denis Paillard based on these properties of the use of deictic elements, pronouns in particular (Paillard 2011). The present analysis confirms it: mol and deskat' introduce the other's speech from two different perspectives. Mol shows that $\mathrm{P}$ is an almost exact reproduction of what was said by the speaker ( $\mathrm{Sx}$ - in the terminology of Paillard). Deskat' shows that $\mathrm{P}$ is an interpretation-translation proposed by the narrator of what was said by the speaker. In this case, there is no guarantee that what is said coincides with the original message: $\mathrm{P}$ corresponds to the narrator's perspective.

This description could explain the stylistic differences between both particles. Mol is used in journalistic discourse; it often accompanies a quotation and is used with set expressions often introduced as a quotation. Deskat' marks a stronger link with the context: its scope is incorporated in the context (constructed by the 
narrator) and is presented as an argument within the development of the context. In (18), the scope of deskat' corresponds to the eventual words of the parents (the speaker) introduced by the narrator to clarify what has been said before: ... told me, that they had spent a lot during holiday and that there would be little left for a birthday party for me.

V kontse avgusta my vozvraščalis' s juga, i roditeli každyj raz čestno predupreždali, čto potratilis' na otdyxe i na prazdnovanie deneg počti ne ostalos'. Deskat', osobyx raznosolov, Dima, ne budet.

'At the end of August we would usually return from the sea, and my parents would tell me that they had spent a lot during the holidays and that there would be little left for a birthday party for me. Deskat', there won't be any delicacies, Dima'.

These semantic differences can be explained by the semantics of the verbs that are the origin of both particles. Mol derives from the verb molvit' (to pronounce), and deskat' is the combination of two verbs: deet' ((дьеть) - the old equivalent of the modern govorit' - (to say) + skazati (скъзати) ) (to say, to talk) (Vasmer 1998).

These three verbs are the verbs of speech in the semantics of which the three components of the communication are included: the participants of the communication (speaker // hearer) that are trying to transmit their own representation of the world using the words. ${ }^{8}$

Govorit' (in Old Russian deet') and molvit' describe the situation from the point of view of the speaker. The verb molvit' designs the speaking activity: a speaker uses words to present his own representation of the world. Govorit' describes the process of the addressed speech: the speaker exteriorizes his own representation of the world and transmits it to the hearer.

The semantics of skazat' is concentrated on the opposite side of this communication schema: on the hearer's possible interpretation based on the words pronounced by the speaker. Skažu tebe neprijatnuju novost' (I'll tell you the unpleasant news) - the news is called unpleasant from the point of view of the hearer (i.e., the news is unpleasant for the hearer). Another example: the expression Skaži pravdu (Tell me the truth) is often used during an interrogation where the speaker (who will become the hearer) is the person who knows the truth and is waiting for the

[8] The basis of this description is the vision of communication proposed by Culioli (2002), in which, in contrast to pragmatic theories, the speaker does not have the decisive position in the communication. In the construction of the enunciation three elements collaborate: words - world - speaker. There is no direct link between an object of the world and the words. That is why there are different ways to say the same thing and the same word can be interpreted in different ways. The world is accessible through the words, but they transmit only the representation of the world that belongs to the speaker. The following schema represents the process of the communication: So (R') - words - S1 (R). So corresponds to the speaker and his/her representation ( $\left.\mathrm{R}^{\prime}\right)$ of the world which s/he tries to transmit by the words. $\mathrm{S} 1$ - the hearer - interprets the words and gets a representation (R) of the world which does not always correspond to the representation of the speaker. 
confession. Otherwise the verb govorit' is used (Govori pravdu. - You have to say the truth). ${ }^{9}$

The semantics of both Russian particles reproduces the schema of the communication but involves different parts of it (speaker vs. hearer), depending upon the semantics of the particular verb that forms the particle. A case in point is the above example illustrating an essential difference between skazat' and govorit'.

\section{[3.4] Italian correspondences}

To create the collection of Italian examples for the present analysis, first of all the Russian words and expressions that generally precede the Russian particles mol and deskat' were distinguished. All the constructions were classified in two different semantic groups: 1) verbs of speech (e.g., skazat', rasskazyvat' - to say, to talk, to narrate) and nouns (e.g., razgovor, reč', rasskaz - conversation, discourse, account) describing communication in general; 2) words and expressions describing the emotional state of the speaker (e.g., ulybat'sja, smejat'sja - to smile, to laugh) or describing gestures and mimics (e.g., pokazyvat', kivat' -to indicate, to nod). The common feature of both groups is the presence of two participants (at least) in the situation that is described. But if in the first group a communicative act is described, that means that some words actually have been pronounced, in the second group, a verbal message is not obligatory, the scope P introduced by mol or deskat' can be a possible narrator's interpretation of the gesture or of the behavior.

In the created collection of Italian examples the elements following the words and expressions of these two groups were analyzed. Two main strategies have been distinguished: the use of punctuation marks that are usually used to indicate the direct speech (dashes, inverted commas, colon), like in (19), (20), and the use of different expressions with the verb dire (to say) (21)-(23).

(19) Paola non risponde; poi nota il mio stupore e sorride - Certo che no! Che domande!

'Paola didn't respond, then she noticed my surprise and smiled - Of course not! What a question!'

(20) Davvero? Tutti appassionati archeologi?! - Leila ride - Non lo so. Di sicuro, sono tipi un po' strani.

'Really? All of them have a passion for archeology?! - Leila laughed - I don't know. But surely, they are strange people.'

(21) Operatori finanziari hanno telefonato alla Banca d'Italia per dire: "Avevate ragione voi e torto la Bundesbank."

[9] For a more detailed analysis, see (Khachaturyan 2006). 
'Financial operators called the Bank of Italy to say: "You were right and the Bundesbank was wrong."'

(22) Ti fanno sentire un perdente e poi ti umiliano appena possono, quasi come per dire: dovete vivere la vostra adolescenza in modo brutale come noi. 'They make you feel like a loser and then they humiliate as soon as they can, as if to say: you have to live your adolescence in a brutal way, as we did.'

(23) Per proteggerti. - Indicando Eric con un cenno della testa, come per dire: per proteggerti da lui.

'To protect you. - He indicated Eric with a nod, as if to say: to protect you from him.'

The expressions with the verb dire have different forms and are used in different contexts. In (21), the expression per dire ([in order] to say) introduces the direct speech (that is marked by inverted commas and the colon) and is used with the verb telefonare (to call) which presupposes a communicative act ${ }^{10}$. In (22) and in (23) come per dire (as if to say) seems to introduce also the direct speech, it is also marked by the colon and the use of the pronouns. But in the examples (22) and (23) the previous verbs do not describe any communicative act: umiliare (to humiliate) describes a behaviour and indicare con un cenno (to indicate with a nod) - a gesture.

These two strategies (punctuation marks and expressions with dire) can be used with any verb or expression: as we have seen it can be a verb of communication (like telefonare in (21)), but also verbs describing behavior or gesture. At the same time a third strategy (that we have distinguished in our collection of examples) is used with a limited group of verbs. It consists to introduce a verb in infinitive (an implicit (non-finite) subordinate clause) and is frequent with verbs describing gestures and mimics (in particular, with the construction fare cenno to make a sign, to nod).

... gli fece cenno di uscire.

(lit. he made him a sign to go out)

... fece cenno al suo collega di avvicinarsi.

(lit. he made a sign to his colleague to come closer)

We have checked then how the Russian verb kivat' (to nod) is used. It can not introduce a non-finite subordinate clause, but it is often followed by the direct speech with the particle mol (like in (10)): in the Russian national corpus 15 occurrences only of the combination kivnul mol (nodded - Past, masc. sing. - mol) have been

[10] According to Govorukho (2006) with Italian verbs of speech the use of the verb dire is almost obligatory. His observation is based on the contrastive analysis of Russian texts and their Italian translations. 
found. This observation can bring us to ask new questions on the syntactic and semantic properties of the verbs of speech and emotion, that will conduct us to a new study.

\section{[4] DISCUSSION AND CONCLUSION}

In the present paper we have analyzed the contexts of the use of two Russian particles mol and deskat' and we have described the differences in their semantics. Mol marks the introduced words like the speaker's words, while deskat' marks that it is a subjective interpretation of the narrator. We have distinguished then with what kind of verbs and expressions these two particles are used mostly often. We have analyzed the Italian verbs and expressions with the same meaning trying to find out the Italian correspondences of the Russian particles. We have distinguished, as two main strategies, the use of the direct speech and of the expression with the verb dire: come per dire.

The literary translations that we have found can confirm this observation. Passages were chosen in which mol or deskat' appeared in the original Russian text. The Italian translation of all of these examples includes the verb dire (say): come a dire / quasi a dire.

(26) Berlioz totčas soobrazil, čto sleduet delat'. Otkinuvšis' na spinku skamji, on za spinoju professora zamigal Bezdomnomu ne protivoreč', mol, emu, no rasterjavšijsja poet etix signalov ne ponjal.

'Berlioz understood immediately what was the best thing to do. Leaning back on the bench, behind the back of the professor he began winking at Bezdomnyj: don't contradict him, mol, but the poet was confused and didn't understand him.'

Berlioz capì subito quello che conveniva fare. Addossandosi allo schienale della panchina, ammiccò a Bezdomnyj dietro le spalle del professore, come a dire: non contraddirlo; ma il poeta, smarrito, non capì quei segnali.

ITALIAN TRANSLATION: come a dire (as if to say).

(27) Publika volnovalas', no idti na stsenu poka nikto ne rešalsja. No nakonets kakaja-to brjunetka vyšla iz desjatogo rjada partera i, ulybajas' tak, čto ej, mol, rešitel'no vse ravno i v obščem naplevat', prošla i po bokovomu trapu podnjalas' na stsenu.

'The public was excited, but nobody dared to go out onto the stage. But finally a dark-haired woman emerged from the tenth row of the stalls and smiled: mol, it was really all the same to her and, in fact, she couldn't care less. Then she took the side stairs onto the stage.'

Il pubblico era emozionato, ma nessuno ancora si decideva a salire sul palcoscenico. Finalmente una brunetta uscì dalla decima fila di platea $\mathrm{e}$, 
sorridendo, quasi a dire che a lei non importava niente e se ne fregava, avanzò e salì sul proscenio per la scaletta laterale.

ITALIAN TRANSLATION: quasi a dire (as if to say).

(28) A supruga ego, očen' počtennaja dama, prosto daže prirevnovala pirata $\mathrm{k}$ Korovjevu i daže ložečkoj postučala ... i čto ž eto, deskat', nas zaderživajut ... Pora i moroženoe podavat'!

'And his wife, a very respectable lady, was even jealous of Koroviev on account of the pirate and banged a teaspoon... so what's the big idea, deskat', what's holding us up...? It's high time they served us our ice cream!'

La sua consorte, una signora rispettabilissima, divenne addirittura gelosa delle premure che il pirata dimostrava per Koroviev, e picchiettò perfino col cucchiaino, come a dire: perché ci fanno aspettare?... Sarebbe ora di servire il gelato.

ITALIAN TRANSLATION: come a dire (as if to say).

In (26), the particle mol introduces the interpretation of the speaker's gesture (a wink); in (27), the emotional verb to smile is followed by the particle mol and its scope; in (28), an action (banging a teaspoon) is interpreted by a speech act. There is no distinction between the particles mol and deskat' in the translations. We do not have enough examples to discuss this fact more in details. But we believe that in Russian the whole context determines which particle (mol or deskat') should be used, while the Italian construction does not have any kind of restrictions.

There are also other correspondences of the Russian particles that should be investigated further. We have seen that some Italian verbs (e.g. fare cenno) can introduce a subordinate clause with an infinitive form, while the Russian verbs with the same meaning are often used with the particle mol. At the same time some Italian verbs (e.g. verbs of communication, like telefonare) need an expression with the verb dire (per dire) that will support the direct speech introduced later (see (21)). ${ }^{11}$ It is difficult to say by the moment how grammaticalized the expression per dire is. We believe that these more formal solutions can be considered as possible correspondences of two Russian particles used in some restricted contexts (depending on the verb).

The starting point of this research was the well-known fact that the conditional mood in Italian can be used with a reportative function but in a quiet limited type of contexts. We have seen now that also the particles mol (and deskat', more rare) can be used with a reportative function, but in a limited type of contexts with particular words or expressions.

[11] This property of some Italian verbs has been mentioned in Govorukho (2006), but a more detailed analysis should be done. 


\section{REFERENCES}

Aijmer, Karin \& A.-M. Simon-Vandenbergen (eds.). 2006. Pragmatic Markers in Contrast. Amsterdam/Atlanta: Elsevier.

Coltier, Danielle, Patrick Dendale \& Philippe De Brabanter. 2009. La notion de "prise en charge" en linguistique. Langue française 162.

Culioli, Antoine. 1990. Pour une linguistique de l'énonciation I. Paris: Ophrys.

Culioli, Antoine. 2002. Variations sur la linguistique. Entretiens avec Frédéric Fau. Klincksieck.

Dendale, Patrick \& Danielle Coltier. 2011. La prise en charge énonciative. Études théoriques et empiriques. Bruxelles: De Boeck Duculot.

Evgenjeva, Anna P. 1999. Slova russkogo jazyka v 4-kh tomakh. Moskva: Russkij jazyk.

Fischer, Kerstin. 2006. Approaches to Discourse Markers. Brill Academic Pub: Elsevier.

Govorukho, Roman. 2006. Eksplicitnost' modusa propozicional'noj ustanovki v ital'janskom jazyke. Voprosy filologii 2. 24-32.

Guentcheva, Zlatka (ed.). 1996. L'énonciation mediatisée. Louvain: Peeters.

Guentcheva, Zlatka. 2011. L'opération de prise en charge et la notion de médiativité. In P. Dendale \& D. Coltier (eds.), La prise en charge énonciative. Études théoriques et empiriques, 117-142. Bruxelles: De Boeck Duculot.

Khachaturyan, Elizaveta. 1998. Funkcii častitcy že i ee perevod na ital'janskij. (Functions of the Russian particle že and its correspondences in Italian). Russkaja filologija 9.327-335.

Khachaturyan, Elizaveta. 2006. Les mots du discours formés à partir des verbes dire / skazat' (en français et en russe): Université Paris 7 - Denis Diderot dissertation.

Mettrich, Réné, E. Faucher \& G. Courdier. 1994-1998. Les invariables difficiles. Dictionnaire allemand-français des particules, connecteurs, interjections et autres "mots de la communication". Université Nancy II.

Paillard, Denis. 1999. Les mots du discours comme mots de la langue I. Le Gré des langues 14. 10-41.

Paillard, Denis. 2011. Marqueurs discursifs et scène énonciative. In S. Hancil (ed.), Marqueurs discursifs et subjectivité, 11-32. Rouen: PU de Rouen. 
Salvi, Giampaolo \& Laura Vanelli. 2004. Nuova grammatica italiana. Bologna: Il Mulino.

Ušakov, Dmitrij N. 2000. Bol'šoj tolkovyj slovar' sovremennogo russkogo jazyka. Moskva: Russkij jazyk.

Vasmer, Max. 1998. Russisches etymologisches Worterbuch. Goeteborg.

Waltereit, Richard. 2001. Modal particles and their functional equivalents: A speech-act theoretic approach. Journal of Pragmatics 33. 1391-1417.

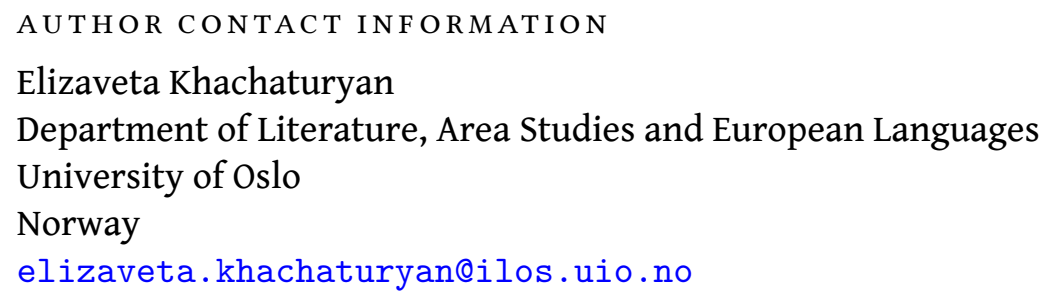

